\title{
THE STAUROGRAM IN EARLY GHRISTIAN MANUSCRIPTS: THE EARLIEST VISUAL REFERENGE TO THE CRUCIFIED JESUS?
}

\author{
LARry W. Hurtado
}

Among the several monograms used by early Christians to refer to Jesus, the so-called "staurogram" or "cross-monogram", which is comprised of the Greek majuscule forms of the letters tau and rho, the vertical line of the rho superimposed on the vertical stroke of the tau, is of particular historical significance. ${ }^{1}$ The specific proposal that I shall support in the present essay is that the Christian use of this device in certain early manuscripts represents the earliest extant visual reference to the crucified Jesus, indeed, considerably prior to what is commonly thought to be the time (fourth or fifth century $\mathrm{CE}$ ) when Christians began to portray the crucifixion of Jesus visually. ${ }^{2}$ This has significant implications well beyond the area of codicology and palaeography, extending also into questions about early Christian beliefs and expressions of piety. ${ }^{3}$ Before we examine this specific

1 The most important previous studies are by K. Aland, "Bemerkungen zum Alter und Entstehung des Christogramms anhand von Beobachtungen bei P66 und P75," Studien zur Überlieferung des Neuen Testaments und seines Textes (Berlin 1967) 173-79; M. Black, "The Chi-Rho Sign-Christogram and/or Staurogram?" Apostolic History and the Gospel: Essays Presented to F.F. Bruce (eds. W.W. Gasque and R.P. Martin; Grand Rapids 1970) 319-27; and, more recently, Erika Dinkler-von Schubert, “CTAYROC: Vom 'Wort vom Kreuz' (1 Kor. 1,18) zum Kreuz-Symbol," Byzantine East, Latin West: Art-Historical Studies in Honor of Kurt Weitzmann (eds. Doula Mouriki et al.; Princeton 1995) 29-39.

2 I provide here further support for a point made earlier by E. Dinkler, Signum Crucis (Tübingen 1967) 177-78, about the historical importance of the tau-rho compendium, who in turn was seconding and amplifying observations by $\mathrm{K}$. Aland, "Neue neutestamentliche Papyri II," NTS 10 (1963-64) 62-79, esp. 75-79; idem, "Neue neutestamentliche Papyri II," NTS 11 (1964-65) 1-21, esp. 1-3. I have discussed the matter more briefly in an earlier essay. See L.W. Hurtado, "The Earliest Evidence of an Emerging Christian Material and Visual Culture: The Codex, the Nomina Sacra and the Staurogram," Text and Artifact in the Religions of Mediterranean Antiquity (eds. S.G. Wilson-M. Desjardins; ESCJ 9; Waterloo, Ontario 2000) 271-88, esp. 279-82.

${ }^{3}$ J. van Haelst, Catalogue des papyrus littéraires Juifs et Chrétiens (Paris 1976) is an indispensable reference work for the use of papyrological data. 
proposal, however, I address some introductory and background questions and set the staurogram into an appropriate historical context.

Several questions obviously present themselves. What is the historical relationship of these various Christian monograms to one another? Were some or all of them created de novo by Christians, or do they represent or include Christian appropriations of ligatures already in use? In any case, what did these devices signify and how did they function in Christian usage, especially in the earliest instances? It is not possible here to deal comprehensively with these questions with reference to all these monograms. Instead, I shall provide some limited discussion of general matters and then focus more specifically on questions about the tau-rho device.

\section{Early Christian Monograms}

In addition to this tau-rho combination, early Christians also made use of several other such devices to refer to Jesus Christ (see Illustration 1). ${ }^{4}$ Perhaps most well known is the chi-rho, which certainly obtained the most widespread and most long-lasting usage, down to the present time. ${ }^{5}$ Less familiar, but also certainly found in ancient Christian usage, were the iota-chi monogram (which with its six points can look like a stylized star) and also the iota-êta. In some later (postConstantinian) instances of Christian usage, we have two or more of these devices used together, as is the case with the Christian inscription from Armant (ancient Hermonthis, Egypt), at the bottom of which there is a tau-rho and an ankh flanked on either side by a chi-rho. ${ }^{6}$ As to their derivation, with the possible exception of the iotaet a compendium, these are all pre-Christian devices and were appropriated by early Christians. ${ }^{7}$ In each case, the Christian innovation

\footnotetext{
${ }^{4}$ See the discussion of "Abbreviations and Monograms" in J. Finegan, The Archaeology of the New Testament: The Life of Jesus and the Beginning of the Early Church (Princeton ${ }^{2}$ 1992) 352-55.

${ }^{5}$ E.g., W. Wischmeyer, "Christogramm und Staurogramm in den lateinischen Inschriften altkirchlicher Zeit," Theologia Crucis-Signum Crucis: Festschrift für Erich Dinkler zum 70. Geburtstag (eds. C. Andresen - G. Klein; Tübingen 1979) 539-50.

${ }^{6}$ Finegan, Archaeology, 387-88, gives a photograph and discussion. The inscription was originally published in 1892, and is thought to have been made sometime between the fourth and sixth centuries CE.

${ }^{7}$ In the following discussion of pre/non-Christian usage of these devices, I draw
} 
was to ascribe new meanings and significance to these devices, so that in Christian usage they referred to Jesus and reflected early Christian piety.

Illustration 1

$\mathbb{X}=\mathrm{XPI \Sigma TO \Sigma}$

$\mathbb{X}=\mathrm{IH} \Sigma \mathrm{OY} \Sigma \mathrm{XPI} \Sigma \mathrm{TO} \Sigma$

$\mathrm{H}=\mathrm{IH}(\Sigma \mathrm{OY} \Sigma)$

P $=$ Used in early manuscripts: $\$ 266, \mathfrak{P} 45, \mathfrak{P} 75$, ca. 200-250 CE

A "monogram" is an interweaving or combination of two (or sometimes more) alphabetic letters, the component-letters of resultant device typically referring to a person's name or title. But such letter-combinations (called "ligatures" and/or "compendia") can also serve other purposes, particularly as abbreviations of common words. For instance, in pre/non-Christian Greek papyri of the Roman period, the chi-rho is used as an abbreviation for several words (e.g., forms of $\chi \rho o v o s)$, and in Greek inscriptions this ligature is found as an

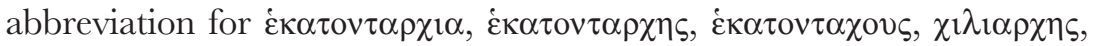
and a few other terms. ${ }^{8}$ As well as the more familiar form of the chi-rho device, one of the two letters superimposed over the other, there are also instances where the one component letter is written above the other. ${ }^{9}$ To cite another early non-Christian instance of the familiar form of this particular ligature, Randolph Richards drew attention to a chi-rho in P.Mur. 164a (line 11), a text of Greek tachygraphic writing on parchment which, with the other manuscripts

upon the following studies: A. Blanchard, Sigles et abbreviations dans les papyrus grecs: Recherches de paleographie (ICSB.S 30; London 1974); K. McNamee, Abbreviations in Greek Literary Papyri and Ostraca (BASP.S 3; Chico 1981); M. Avi-Yonah, Abbreviations in Greek Inscriptions (The Near East, $200 B C^{-} A D$ 1100) (repr. Chicago 1974; originally published as a supplement to Quarterly of the Department of Antiquities in Palestine 9 [1940]). E. Dinkler-von Schubert, "Wort vom Kreuz," 33-34, also surveys the pre/nonChristian usage of the tau-rho and the chi-rho devices. The most comprehensive survey of ancient monograms known to me is V. Gardthausen, Das alte Monogramm (Leipzig 1924), but unfortunately his discussion of earliest Christian monograms (esp. 73-79) is clearly incorrect in light of subsequently discovered evidence such as I discuss here.

${ }^{8}$ See, e.g., Don Pasquale Colella, "Les abbreviations $\bullet$ et $\mathfrak{X}$ (XP)," RB 80 (1973) 547-558, who comments on the likely import of chi-rho marks on (non-Christian) amphorae.

${ }_{9}$ Examples cited by K. McNamee, Abbreviations, 118; A. Blanchard, Sigles, 26 (n. 36); and M. Avi-Yonah, Abbreviations, 112. 
found in Wadi Murabba'at, is probably to be dated to the Jewish revolt of $132-35 \mathrm{CE}^{10}$ In yet another instance, the device also appears in the margin of a hypomnema on Homer, Iliad, dated to the first century BCE, the chi-rho here a sign for $\chi \rho \eta \sigma \tau o v$ (marking passages "useful" for excerpting). ${ }^{11}$

The tau-rho combination, the focus of this discussion, appears in pre/non-Christian usage as an abbreviation for $\tau \rho($ oло $)$, $\tau \rho(1 \alpha \kappa \alpha \varsigma)$, and $\mathrm{T} \rho(\mathrm{o \kappa ov} \delta \alpha \varsigma) .{ }^{12}$ Among specific noteworthy instances, there is the use of this device on some coins of King Herod (37-4 BCE), the taurho intended to identify them with the third year of his reign. ${ }^{13}$

The iota-chi combination was an archaic form of the Greek letter $p s i$, and was also sometimes used on Roman-era coins (probably as a numerical symbol). Moreover, there is an obvious similarity to sixpointed devices used for decoration ubiquitously in various cultures, and sometimes as stylized stars. ${ }^{14}$

The uses of the iota-êta combination, however, in relevant surveys of the data with which I am acquainted are all Christian instances, comprising the first two letters of the name Inoovs and intended as an obvious reference to him..$^{15}$ But there are similar ligatures of other letters in non-Christian Greek documentary papyri, such as the combination of $m u$ and epsilon (for $\mu \varepsilon \gamma \alpha \varsigma, \mu \varepsilon \rho 1 \varsigma, \mu \varepsilon \tau o \chi 0 \varsigma$, and other terms). ${ }^{16}$ So, even if the specific iota-êta combination may have been first employed as a monogram by Christians, the Christian use of other ligatures, for example the stylized six-pointed decorative device (iota-

${ }^{10}$ E. Randolph Richards, The Secretary in the Letters of Paul (Tübingen: J.C.B. Mohr [Paul Siebeck], 1991), 40-41. The full description of the manuscript is in P. Benoit et al., Les grottes de Murabba'āt (DJD, 2; Oxford: Oxford University Press, 1961), 275-79.

11 E. G. Turner, Greek Manuscripts of the Ancient World (2nd rev. ed.; London: Institute of Classical Studies, 1987), plate 58.

12 K. McNamee, Abbreviations, 119; M. Avi-Yonah, Abbreviations, 105.

${ }^{13}$ B. Kanael, "The Coins of King Herod of the Third Year," FQR 62 (1951-52) 261-264; idem, "Ancient Jewish Coins and their Historical Importance," Biblical Archaeologist 26 (1963) 38-62, esp. 48. Use of devices involving a tau-rho ligature were also noted on items from Dura Europos, at least some instances likely craftsmen's marks. See R.N. Frye, J.F. Gillam, H. Inghold and C.B. Welles, "Inscriptions from Dura-Europos," Tale Classical Studies 14 (1955) 123-213, esp. 191-94.

${ }^{14}$ For instances and discussion, see M. Sulzberger, "Le Symbole de la Croix et les Monogrammes de Jésus chez les premier Chrétiens," Byzantion 2 (1925) 337-448, esp. 394-95, who also cites Gardthausen, Das alte Monogramm, 76-77.

15 Avi-Yonah, Abbreviations, 72.

16 Blanchard, Sigles, 4. 


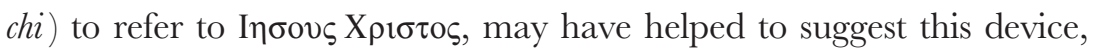
and, in any case, the joining of various letters to form a ligature was familiar to readers of the time, especially in documentary texts and inscriptions.

As indicated already, in Christian usage, all of the monograms/ compendia in question served in one way or another as references to Jesus. Thus, the Christian appropriation of them all reflects the enormous place of Jesus in early Christian devotion, and these curious devices thereby became themselves expressions of this piety. ${ }^{17}$

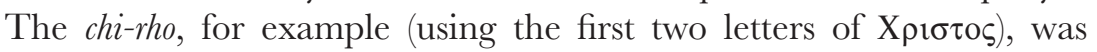
a direct reference to "Christ" and became one of the most familiar and widely-used emblems in Christian tradition. ${ }^{18}$ The iota-chi seems to have functioned mainly as a combination of the initial letters of

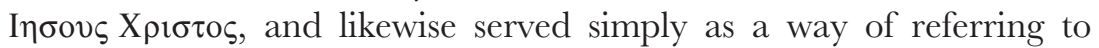
him, as did the iota-êta, which was formed from the first two letters of Inбovs. ${ }^{19}$

Moreover, it is important to note that all of these devices represent visual phenomena, and so, as reverential references to Jesus in early Christian usage, they have a certain iconographic function and significance, which should be recognized. The earliest Christian use of these devices, which takes us back at least to the late second century and quite possibly earlier, represents the emergence of what we may term a Christian "visual culture". I shall return to this point later. But in the case of the Christian use of tau-rho monogram, there are also interesting distinctives that now require further attention.

\footnotetext{
${ }^{17}$ See now, L.W. Hurtado, Lord Jesus Christ: Devotion to Jesus in Earliest Christianity (Grand Rapids 2003).

${ }^{18}$ Note, e.g., the use of the chi-rho in the Trisomus inscription in the Catacomb of Priscilla (Rome), a prayer to God, the last line of which reads " $\sigma o t \delta o \xi \alpha \varepsilon v[\chi \rho]$." For full text and discussion, see Finegan, Archaeology, 380. For other instances, see M. Burzachechi, "Sull' Uso Pre-Costantiniano del Monogramma Greco di Christo," Rendiconti della Pontificia Accademia Romana di Archeologia, Series III 28 (1955-56) 197-211.

${ }_{19}$ Finegan, Archaeology, 379-380, gives a photo and discussion of a painted sign in the Catacomb of Priscilla that appears to have a iota-êta compendium, but in this instance the horizontal stroke extends through and beyond the letters, giving the appearance of three connected equilateral crosses.
} 


\section{The Staurogram: Origin}

The first observation to make is that, whereas all of the other Christian letter-compendia that I have mentioned are true monograms, the component letters in each case directly referring to Jesus by name and/or a christological title, the tau-rho combination did not have any such function. Its component letters neither derive from, nor refer to, Jesus' name or any of the familiar christological titles. Indeed, in Christian usage, the two component letters in this device do not appear to refer to any words at all. So what suggested the Christian appropriation of this particular letter-compendium? ${ }^{20}$ Furthermore, although the tau-rho seems to have had some later usage simply as a free-standing reverential cipher for the figure of Jesus, and/or perhaps simply as an emblem intended to signify Christian faith, what was its initial function and significance, and when might it first have appeared in Christian usage?

Let us first address the question of origins. Our most important evidence, and certainly the earliest, is provided by the instances of this device in some very early Christian manuscripts. ${ }^{21}$ We may begin with Papyrus Bodmer II $\left(\mathfrak{P}^{66}\right)$, the extant portion of a codex of the Gospel of John (chapters 1-14 relatively well preserved, the rest of John through chapter 21 in very fragmentary condition), and dated palaeographically to ca. $200 \mathrm{GE} .{ }^{22}$ In this manuscript the noun

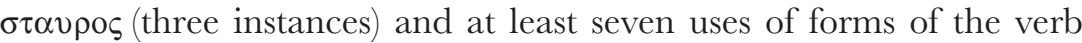

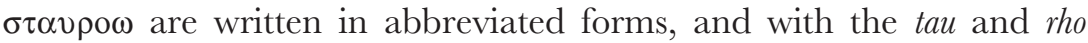
of these words written as a compendium. In each case, the statement in which the noun or verb appears refers to Jesus' cross/ crucifixion. ${ }^{23}$

${ }^{20}$ Cf. E. Dinkler-von Schubert, "Wort vom Kreuz," 32, who judged the question no closer to an answer. I acknowledge the difficulty involved in being entirely precise, as the following discussion will show. But I do not think that we are entirely without clues and a likely basic association of the device in earliest Christian use.

${ }^{21} \mathrm{~K}$. Aland has the credit for first drawing scholarly attention to this evidence in two important articles (cited above in n. 2) in successive volumes of NTS in the early 1960 s.

${ }^{22}$ V. Martin, Papyrus Bodmer II: Evangile de Jean Chap. 1-14 (Cologny-Geneva 1956); idem, Papyrus Bodmer II, Évangile de Jean, Supplément, Chaps. 14-21 Cologny-Geneva 1958); V. Martin and J.W.B. Barns, Papyrus Bodmer II, Supplement, Évangile de Fean chap. 14-2, Nouvelle edition augmentée et corrigée (Cologny-Geneva 1962).

${ }^{23} \mathrm{~K}$. Aland identified instances of $\sigma \tau \alpha v \rho \circ \varsigma$ abbreviated and with the tau-rho in John 19:19, 25, 31, and abbreviated forms of $\sigma \tau \alpha v \rho \circ$ with this device in John 19:6 
Likewise, in $\mathfrak{P}^{75}$, dated to about the same time and comprising portions of the Gospel of Luke (Papyrus Bodmer XIV) and the Gospel of John (Papyrus Bodmer XV), there are further instances of the tau-rho compendium used in abbreviated forms of the same two Greek words. ${ }^{24}$ But the scribal practice in this manuscript was not so consistent. In all three cases where $\sigma \tau \alpha v \rho \circ \varsigma$ appears in the extant portions of Luke $(9: 23 ; 14: 27 ; 23: 26)$ the word is written in an abbreviated form, and in two of these cases $(9: 23 ; 14: 27)$ the taurho compendium is also used..$^{25}$ In the six extant occurrences of the verb $\sigma \tau \alpha v \rho o \omega$, however, the word is abbreviated twice $(23: 33 ; 24: 7)$, and in the other four cases is written fully (23:21 [two], 23; 24:20). Only at Luke $24: 7$ in $\mathfrak{P}^{75}$ is there a verb-form extant with the taurho compendium. ${ }^{26}$

These abbreviations of $\sigma \tau \alpha v \rho \circ$ and $\sigma \tau \alpha v \rho \circ \omega$ (in each case with a horizontal stroke over the abbreviation) mean that the copyists in question were extending to them the special, and apparently distinctively Christian, abbreviation-practice now commonly referred to as "nomina sacra". ${ }^{27}$ But, as Aland observed, on the basis of these two early, and roughly contemporary, manuscripts, it appears that the Christian practice of writing $\sigma \tau \alpha v \rho o s$ as a nomen sacrum was somewhat more quickly and more firmly established than was the case for the verb $\sigma \tau \alpha v \rho o \omega .^{28}$

We should also note that in the Vienna fragment of $\mathfrak{P O}^{45}$ (dated ca. 200-250 CE), at Matthew 26:2 (the sole place where either the

(three), 15 (two), 16, 18 ("Neue neutestamentliche Papyri II," NTS 10 [1963-64] 75 , and further possible cases in 19:17, 20. Cf. instances identified by Martin and Barns in the 1962 augmented and corrected edition of chapters 14-21 of $\mathfrak{P}^{66}$ : forms

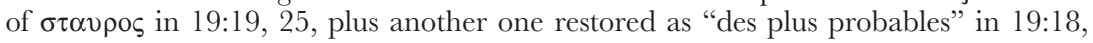
and forms of $\sigma \tau \alpha v \rho o \omega$ in 19:6 (two), 16, 18, plus a proposed restoration of another instance in 19:20. My own examination of the photos published in their 1962 edition enabled me to verify clear instances in abbreviated forms of $\sigma \tau \alpha \cup \rho o \varsigma$ in 19:19, 25 , and 31, and in forms of $\sigma \tau \alpha v \rho o \omega$ in 19:6, 15, 16, and 18 .

${ }_{24}$ V. Martin and R. Kasser Papyrus Bodmer XIV, Evangile de Luc, chap. 3-24 (ColognyGeneva 1961).

${ }_{25}$ The statements in Luke 9:23 and 14:27 have Jesus demanding his followers to "take up daily" and "bear" their own cross. But in each case, there is a clearly implied reference to his crucifixion.

${ }_{26}$ Martin and Kasser, Papyrus Bodmer XIV, 18; K. Aland, "Neue Neutestamentliche Papyri II," NTS 11 (1964-65) 2. The extant portions of John in $\mathfrak{P}^{75}$ (P. Bodmer $\mathrm{XV}$ ) do not include any uses of $\sigma \tau \alpha v \rho \circ$ or $^{\sigma \tau \alpha v \rho o \omega .}$

${ }^{27}$ For discussion and references to other key studies, see L.W. Hurtado, "The Origin of the Nomina Sacra: A Proposal," FBL 117 (1998) 655-73.

${ }_{28}$ Hurtado, "Origin," 2. 
relevant noun or verb appears in the extant portions of the manuscript) the verb-form $\sigma \tau \alpha \nu \rho \omega \theta \eta v \alpha \mathrm{l}$ ("to be crucified") is written in a contracted form and with the tau-rho compendium. ${ }^{29}$ That is, we have three early third-century Christian manuscripts with this curious device, in all of which it is used in the same way, as part of a nomina sacra treatment of the Greek words for "cross" and "crucify".

It is unlikely that we happen to have the very first Christian usages of the tau-rho. We must suppose that this device had already been in Christian usage for some period of time for it to have been used independently by the copyists of these three manuscripts. ${ }^{30}$ This obviously means that we should date the initial Christian appropriation of the tau-rho device at least as early as the final decades of the second century, and quite plausibly somewhat earlier. It is a very interesting question as to whether the earliest appropriation of the tau-rho was made by copyists of still earlier Christian manuscripts in references to Jesus' cross/crucifixion, or whether there was some previous and/or wider Christian usage of this ligature, i.e., beyond its use in Christian manuscripts. Unfortunately, I know of no clear evidence to settle the matter. $\mathfrak{P}^{45}, \mathfrak{P}^{66}$ and $\mathfrak{P}^{75}$ offer us the earliest extant Christian uses of the tau-rho device, and in all these cases it is used in references to Jesus' cross/crucifixion. But we can say with some confidence that these three early manuscripts are not likely the first such uses of the tau-rho. Instead, $\mathfrak{P}^{45}, \mathfrak{P}^{66}$ and $\mathfrak{P}^{75}$ offer us evidence of a Christian appropriation of the tau-rho device that (whatever and whenever its origin) was already becoming familiar in Christian circles at the time that these copyists worked.

${ }^{29}$ Gerstinger, "Ein Fragment des Chester Beatty-Evangelienkodex in der Papyrussammlung der Nationalbibliothek in Wien (Pap. Graec. Vinob. 31974)," Aeg. 13 (1936) 67-72, esp. 69; T.J. Kraus, "Ad fontes: Gewinn durch die Konsultation von Originalhandschriften am Beispiel von P.Vindob.G 31974," Bib. 82 (2001) 2-17 (with plate). The fragment (Matt. 25:41-26:39) forms part of Chester Beatty Papyrus I (van Haelst 371), 30 leaves of a codex originally comprising the four Gospels (in "Western" order) and Acts. See esp. T.C. Skeat, "A Codicological Analysis of the Chester Beatty Papyrus Codex of Gospels and Acts (P45)," Hermathena 155 (1991) 27-43, reprinted in The Collected Biblical Writings of T.C. Skeat (ed. J.K. Elliott; NovTSup 113; Leiden 2004) 141-57.

30 Although these three manuscripts are dated to a roughly similar period, the differences in scribal hands and a number of other features indicate that $\mathfrak{P}^{45}, \mathfrak{P}^{66}$ and $\mathfrak{P}^{75}$ must derive from three distinguishable settings, which means that the copyists likely worked independently of one another. 
In any case, this important manuscript evidence about the Christian appropriation of the tau-rho device rather clearly means that earlier (and still echoed) views, such as the influential analysis of early Christian Jesus-monograms by Sulzberger must be judged incorrect on a couple of important matters, and that any history of early Christian symbols must take account of this. ${ }^{31}$ Most obviously, contra Sulzberger, the Christian tau-rho monogram did not first emerge in the post-Constantinian period, and is not to be understood as a derivation from a prior Christian usage of the chi-rho. ${ }^{32}$ Instead, the evidence cited from $\mathfrak{P}^{45}, \mathfrak{P}^{66}$ and $\mathfrak{P}^{75}$ gives instances of the Christian use of the tau-rho considerably earlier than datable instances of the Christian usage of the chi-rho, and well before Constantine! Indeed, as K. Aland noted several decades ago, to go by this manuscript evidence, the earliest Jesus-monogram appears to be the tau-rho, not the chi-rho. ${ }^{33}$ Moreover, and perhaps of equal significance, the instances

${ }^{31}$ M. Sulzberger, "Le Symbole de la Croix et les Monogrammes de Jésus chez les premiers Chrétiens," Byzantion 2 (1925) 337-448. A very similar schema of the evolutionary development of Christian monograms was set out earlier and briefer by L. Spence, "Cross," Encyclopedia of Religion and Ethics IV (1911) 324-30. Likewise in need of correction is the analysis by M.A. Frantz, "The Provenance of the Open Rho in the Christian Monograms," American Fournal of Archaeology 33 (1929) 10-26, esp. $10-11$.

${ }_{32}$ M. Sulzberger also made several other claims that have been influential but are shown to be incorrect by the manuscript evidence: that the earliest Christian symbol for Jesus' cross was the chi, not the tau (ibid., "Symbole", 366), that as a general rule "on ne trouve ni croix, ni monogrammes de Jésus, ni representations de la Passion avant le quatrième siècle" (ibid., 371), that possibly with rare exceptions there are no direct representations of Jesus' cross before Constantine (ibid., 386), that the iota-chi is the earliest-attested Jesus-monogram, and neither the chirho nor the tau-rho can be dated prior to the fourth century (ibid., 393). Granted, Sulzberger wrote before the Chester Beatty and Bodmer papyri were available to scholars, and he leaned heavily on inscriptional data. Based on Christian manuscripts then available, he observed that "Il est remarquable que, dans les papyrus chrétiens, on ne trouve ni croix ni monogramme avant le Ve siècle" (ibid., 446). But he cannot be excused entirely. Even on the basis of evidence available to him, he had reason to question his views. But, instead, he seems to have allowed what seemed to him an elegant theory to determine how to handle evidence, rather than shaping his theory to fit the evidence. To cite an important instance, in considering a Christian inscription from Egypt which ends with a tau-rho flanked by an alpha and an omega, he preferred to assume that these were added "après coup" (ibid., 376-77). $\mathfrak{P}^{45}, \mathfrak{P}^{66}$ and $\mathfrak{P}^{75}$ now clearly confirm that this was a serious mis-judgment. The influence of his weighty article is reflected in writings of many other historians of early Christian art, e.g., C.R. Morey, Early Christian Art (Princeton $\left.{ }^{2} 1953\right) 128$.

${ }^{33}$ I restrict attention here to the use of these ligatures, and cannot engage the 
of the tau-rho device in these manuscripts (i.e., in abbreviations of the Greek words for "cross" and "crucify" in New Testament passages referring to Jesus' death), the earliest Christian uses extant, show us that this compendium was used in this early period, not simply as a general symbol for Jesus, but more specifically to refer reverentially to Jesus' death. ${ }^{34}$

In an article on $\mathfrak{P}^{66}$ and $\mathfrak{P}^{75}$, Jean Savignac noted that evidence indicating the chronological priority of the tau-rho over the chi-rho rendered Sulzberger's view of the origin of the Christian use of these two ligatures invalid, but Savignac's own proposal seems to me no more persuasive. Based on the frequently-noted Armant Christian inscription from the fourth century $\mathrm{CE}$ (or later) which features a taurho and the hieroglyphic ankh-sign flanked by two chi-rhos, he suggested that the appropriation of the tau-rho derived from its visual similarity to the ankh (the hieroglyphic significance of the latter being "life"), which, he further proposed, had been adopted previously, perhaps in certain Valentinian circles in Egypt. ${ }^{35}$ Savignac recognized that, in general, early Christians, especially those whose faith remained more influenced by Jewish monotheistic concerns, may have been loath to adopt a pagan religious symbol such as the ankh. But, claiming the appearance of an ankh on the final page of the copy of the Gospel of Truth in the Jung codex, and taking the widelyshared view that this text derives from Valentinian circles, Savignac offered this as a basis for thinking that Valentinians may have been more ready to adopt this ancient Egyptian symbol for "life", interpreting it as referring to the life given through Jesus. There are, however, major problems with Savignac's proposals.

First, his core thesis does not adequately respect the respective dates of the evidence. The earliest verifiable Christian uses of the

\footnotetext{
wider questions about other early Christian symbols, among which fish are promi-

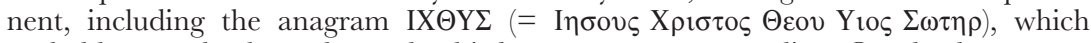
probably goes back to the early third century or even earlier. On the latter, see, e.g., G.F. Snyder, Ante Pacem: Archaeological Evidence of Church Life before Constantine (Macon 1985), 24-26 (with further references), and esp. F.J. Dölger, IX $\Theta Y \Sigma$. Das Fisch-Symbol in frühchristlicher Zeit (Münster 1928).

${ }^{34}$ K. Aland, "Neue Neutestamentliche Papyri II," NTS 10 (1963-64) 78.

${ }^{35}$ J. de Savignac, "Les Papyrus Bodmer XIV et XV," Scriptorium 17 (1963) 50-55, esp. 51. Much earlier, Gardthausen (Das alte Monogramm, 78-79) had proposed that the chi-rho was the earliest Christian monogram, and that a subsequent Christian use of the tau-rho derived from the ankh. Both of his proposals are now refuted by the evidence of early Christian manuscripts. 
ankh symbol are considerably later than the uses of the tau-rho device in $\mathfrak{P}^{66}, \mathfrak{P}^{75}$ and $\mathfrak{P}^{45} \cdot{ }^{36}$ It is simply not sound historical method to derive the clearly-attested Christian use of the tau-rho from a supposedly prior Christian use of the ankh, when the evidence for the Christian use of the latter device is much later. It is always a better approach to develop a theory out of the evidence, taking the dates of evidence seriously. If there was any causative relationship between the Christian appropriation of the ankh and the tau-rho, the chronological data actually make it more likely that Savignac's proposal should be stood on its head: The appropriation of the ankh may well have resulted from its visual resemblance to the tau-rho device. In any case, the sequential relationship between the Christian appropriation of the tau-rho and the ankh is rather clearly the opposite to Savignac's theory.

There is a second problem in Savignac's proposal, and it is not confined to him. It is a mistake to presume that the Christian appropriation of the various Jesus-monograms must have involved one initial monogram from which subsequent Christian appropriation of the others then developed. It seems to me that this insufficientlyexamined assumption contributed to the misjudgments of Sulzberger as well as Savignac, leading them to posit their respective developmental schemes, even although the evidence did not actually suggest either one.

Why should we suppose that there had to be one initial Jesusmonogram from which the others somehow developed? ${ }^{37}$ It is at least

${ }^{36} \mathrm{~K}$. Aland disputed whether an ankh could really be read on the last page of the Jung Codex ("Neue Neutestamentliche Papyri II," NTS 11, 2-3). But, whatever the valid reading of this particular manuscript, the ankh symbol indisputably appears elsewhere in the Nag Hammadi texts, particularly on the leather cover of Codex 2 and at the end of the text titled "The Prayer of the Apostle Paul". Moreover, other data such as the Armant inscription mentioned above rather clearly indicate Christian appropriation of the ankh by the fourth to sixth centuries CE, and this appropriation seems not to have been particularly connected to Valentinian circles. Although some of the Nag Hammadi texts may well have originated in Greek-speaking "gnostic" circles, the fourth-century Coptic manuscripts of the Nag Hammadi collection were likely prepared by monastic scribes who were certainly strongly ascetic, but not particularly "Valentinians". See, e.g., the discussion by J.M. Robinson (Gen. Ed.), The Nag Hammadi Library (Leiden ${ }^{2} 1988$ ), 10-22.

${ }^{37}$ Is the uncritical assumption of such a schema simply indicative of how Darwinian concepts of unilinear evolution have become so much a part of Western intellectual culture that we assume that the "historical" explanation of anything must have proceeded along these lines? 
as reasonable to view the Christian uses of the various Jesus-monograms as reflecting quasi-independent appropriations of at least some of the various pre/non-Christian compendia, each of the appropriations suggested to Christians by the perceived capability of the respective devices to express Christian faith and piety. ${ }^{38}$ As we have noted already, all of the devices in question here were in pre/nonChristian use already, and thus were readily available. All that was needed for the appropriation of any one of them was for some Christian to perceive it in a new light, seeing in it a reference to Jesus. Of course, it is in principle possible that an initial Christian appropriation of one of these compendia may have helped to stimulate Christians to seize upon others as well. But this seems to me no more than a possibility. In any case, even such a scenario does not amount to the various Jesus-monograms evolving out of an initial one.

In summary of the import of the chronological data, the earliest extant Christian uses of the tau-rho are notably prior to the attested Christian usage of any of the other ligatures. This alone makes it unlikely that the Christian appropriation of the tau-rho was directly influenced by prior Christian use of any of these other devices. Indeed, the chronological data suggest strongly that the tau-rho may have been the first of the several ligatures that were appropriated by early Christians to refer to Jesus. Likewise, the earliest Christian use of the tau-rho was probably not derived from Christian use of the ankh, for this is attested only considerably later.

Also, it is significant that, in distinction from the other ligatures, the Christian tau-rho was not functionally a monogram. That is, unlike the other ligatures in question, the tau-rho was not derived from, and did not refer to, the name of Jesus or Christological titles. This is a further reason for doubting that the Christian appropriation of the tau-rho ligature was derived from a supposedly prior use of one of the others. In earliest Christian usage, the tau-rho alone appears as

${ }^{38}$ By "quasi" independent, I mean that the appropriation of the various devices as Jesus-monograms obviously happened among circles of Christians, who to a greater or lesser extent shared features of faith and piety. Moreover, Christians clearly made efforts to "network" with other Christian circles, both locally and translocally. So, if any given ligature was first adopted in some circle of Christians, they may well have known of the appropriation of one or more of the other ligatures among their own or other circles of Christians. 
part of the nomina sacra treatment of certain words ( $\sigma \tau \alpha v \rho o \varsigma$ and $\sigma \tau \alpha v \rho o \omega)$, and simply functioned differently as an early Christian symbol. Indeed, an answer to the question of how the Christian use of the tau-rho originated is probably connected to its earliest function. So, to this question we now give further attention to this question.

\section{The Staurogram: Earliest Function and Signifigance}

The difference in derivation corresponds to a difference in function. To reiterate an important point, unlike the other compendia, the tau-rho did not function as a direct allusion to Jesus by name or title. In the earliest instances of the tau-rho, of course, the two letters are two of those that make up the Greek words for "cross" and "crucify". But this in itself is unlikely to explain either the reason for the Christian appropriation of the ligature or its original Christian symbolic meaning. The earliest manuscript evidence cited earlier shows that the writing of the Greek words in question as nomina sacra did not consistently involve the use of the tau-rho ligature, which strongly suggests that the two phenomena arose independently.

A more likely approach to the origin and original function/ significance of the tau-rho is readily available. We know that the Greek letter tau was invested with symbolic significance by Christians very early, specifically as a visual reference to the cross of Jesus. In the Epistle of Barnabas 9:7-9 (dated sometime 70-130 CE), commenting on the story of Abraham's rescue of Lot with a company of 318 servants (Gen. 14:14), the number represented by the use of the Greek letters TIH, the author interprets the two letters iota and etta (the first two letters of Inбovs), as referring to Jesus, and letter tau as a reference to (and prediction of) Jesus' cross. ${ }^{39}$ We have other

39 This rendering of the number in Gen. 14:14 is clearly instanced in, e.g., the Chester Beatty Genesis Manuscript (Chester Beatty Papyrus IV, Rahlfs 961, fourth century CE), and was almost certainly used also in the early fragment of Genesis, P.Yale 1 (P.Yale inv. 419, van Haelst 12, variously dated from early second to third century CE). Although there is a lacuna in this fragment at this spot, the space is scarcely adequate to have accommodated the number written out in words. The likelihood that the number was written as $\mathrm{TIH}$ is one of the reasons that most papyrologists take P.Yale 1 to be an early Christian copy of Genesis. On this fragment, see esp. C.H. Roberts, "P.Yale 1 and the Early Christian Book," Essays in Honor of C. Bradford Welles (ed. A.E. Samuel; American Studies in Papyrology 1; New Haven 
evidence confirming that the Greek letter tau was viewed by Christians in the second century GE as a visual symbol of the cross of Jesus. Indeed, Justin Martyr (1 Apol. 55) indicates that second-century Christians could see visual allusions to Jesus' cross in practically any object with even the remote shape of a $\mathrm{T}$ (e.g., a sailing mast with cross-beam, a plow or other tools with a cross-piece of any kind, the erect human form with arms extended, even the face with the nose extending!).$^{40}$ In another fascinating passage $(1$ Apol. 60), Justin

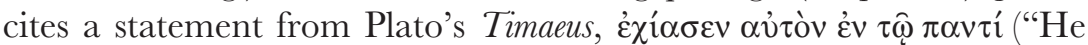
placed him crosswise in the universe"), which Justin appropriates as a reference to Jesus ("concerning the Son of God," 1 Apol. 60:1).

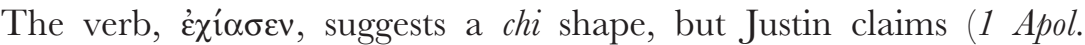
$60: 2-5)$ that Plato derived the idea from a misunderstanding of the account where Moses was directed by God to erect a brass object for the healing of the Israelites who had been bitten by serpents (Num. 21:8-9). Justin claims that Plato inaccurately understood the object that Moses made as chi-shaped, when in fact it was in the figure of a cross. ${ }^{41}$ In light of his earlier comments about cross-shaped objects in 1 Apol. 55, we can say that Justin almost certainly had something T-shaped object in mind here as well in claiming that Moses' brass object was "the figure of a cross". ${ }^{42}$

Closer to the probable date of the manuscripts in which the taurho device appears, there is another significant piece of evidence. Tertullian (Contra Marcionem 3:22), citing the passage in Ezekiel where God directs an angel to mark the foreheads of the elect, takes the "mark" as the Greek letter tau, and then comments as follows:

1966) 27-28; and the stimulating reflections by E. Dinkler, "Papyrus Yalensis 1 als ältester bekannter christlicher Genesistext: Zur Frühgeschichte des Kreuz-Symbols," Im Zeichen des Kreuzes: Aufsätze von Erich Dinkler (eds. O. Merk-M. Wolter; Berlin-

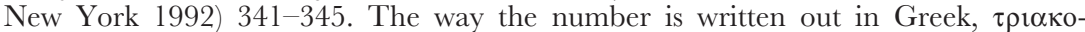

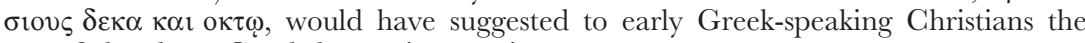
use of the three Greek letters in question.

${ }^{40}$ Somewhat later, Minucius Felix (Octavius, 29; ANF 4:191) echoes basically the same attitude. On the history and various types of cross-symbols, see, e.g., Erich Dinkler and Erika Dinkler-von Schubert, "Kreuz," Lexicon der christlichen Ikonographie (ed. E. Kirschbaum; Rome 1968), vol. 2 cols. 562-90.

${ }^{41}$ Justin says of Plato's putative reading of the Numbers account, " $\mu \eta \delta \varepsilon \dot{\varepsilon} v o \eta ́ \sigma \alpha \varsigma$

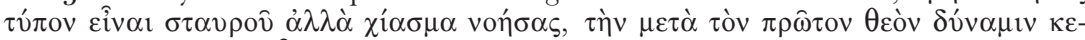

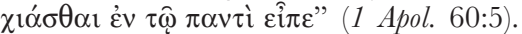

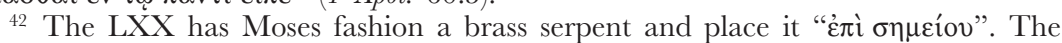
Hebrew has Moses place a brass serpent on a "ע" ("pole"). 
Now the Greek letter Tau and our own [Latin] letter $\mathrm{T}$ is the very form of the cross, which He [God] predicted would be the sign on our foreheads in the true Catholic Jerusalem ...43

So it seems most reasonable to see the Christian appropriation of the tau-rho ligature as connected to, and likely prompted by, this strong association of the Greek letter tau with Jesus' cross.

This certainly also fits with the fact that the earliest known Christian uses of the tau-rho device are in the special "nomina sacra" writing of the words for "cross" and "crucify".

But what is the significance of the superimposed letter rho in the Christian use of the tau-rho compendium? Many years ago, F.J. Dölger cited intriguing evidence indicating that the Greek letter rho (which $=100$ ) could represent "good fortune" (by "isosephy" the letters in the expression "ह่ $\pi$ ' $\alpha \gamma \alpha \theta \alpha$ " amount to 100). ${ }^{44}$ Dölger also cited a statement by the Christian teacher and hymnist Ephraem the Syrian (ca. 306-73 cE) that is of interest. The statement comes in Ephraem's comments on the meaning of the Christian symbol apparently comprising a tau-rho with the alpha and omega placed under the left and right horizontal arms of the tau. Ephraem says that in this device we have represented the cross of Jesus (the tau, for which he says that Moses' outstretched hands are an OT type), the alpha and omega signifying that Jesus ("the crucified one") is the beginning and end, and, he continues, "The P signifies $\beta$ oń $\theta_{1} \alpha$ [= "help"], the numerical value of which is $100 " .45$

Dölger took Ephraem's statement to mean that he interpreted the tau-rho device by isosephy as signifying "Salvation is in the Cross"

43 Contra Marcionem was written 207 GE. I cite here the translation of Tertullian in ANF 3 (pp. 340-341). The LXX of Ezek. 9:4, however, has the angel directed

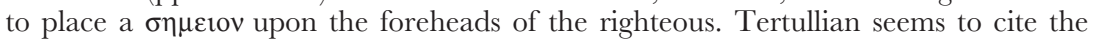
reading that is reported by Origen to have featured in the translations of Theodotion and Aquila (Origen, Selecta in Ezekiel; Migne, 3.802), which is a more literal rendering of the Hebrew ((ת).

${ }_{44} \varepsilon-5, \pi-80, \alpha-1, \gamma-3, \alpha-1, \theta-9, \alpha-1=100$. F.J. Dölger, Sol Salutis: Gebet und Gesang im christlichen Altertum (Münster ${ }^{3} 1972$ [1925]) 73-74, citing Artemidorus of Ephesus ("Daldianus", late 2nd cent. GE), and an inscription from Pergamon from the time of Hadrian.

${ }^{45} \beta-2,0-70, \eta-8, \theta-9, \mathbf{l}-10, \alpha-1=100$. I translate the Greek from the citation of Ephraem in Dölger, Sol Salutis, 74, n. 2). On Ephraem, see, e.g., K. McVey, "Ephraem the Syrian," Encyclopedia of Early Christianity (1988) 376-377 (with bibliography). McVey describes Ephraem as holding "a vision of the world as a vast system of symbols or mysteries" (ibid., 376). 
or "the Cross is our help" ${ }^{46}$ This seems to me a persuasive inference. Might this be also the original meaning and function of the tau-rho device? Is this how the scribes who first employed the tau-rho in the nomina sacra forms of $\sigma \tau \alpha v \rho o s$ and $\sigma \tau \alpha v \rho o \omega$ regard the device? Ephraem is, of course, considerably later than the time of the manuscripts that we are focusing on here, and so the question is whether his numerical interpretation manifests his own fascination with such things or reflects more broadly early Christian interpretation of the tau-rho.

To be sure, we have evidence that at least some Christians in the first and second centuries engaged in isosephy. Most familiar, of course, is the number of "the beast" in Revelation 13:17-18, which is "the number of his name". ${ }^{47}$ We should also recall the interpretation of the 318 servants of Abraham noted previously in Epistle of Barnabas (9:7-9). In an earlier publication, I have offered support for C.H. Roberts' proposal that the nomina sacra writing of Jesus' name as IH may have derived from an association of the numerical value of these two Greek letters (18) with the same numerical value of the Hebrew word for life, $r^{48}$ But even if this particular proposal is not deemed persuasive to all, it is clear that some Christians from the earliest period were interested in using numerical symbolism to express their faith. ${ }^{49}$ So, it is in principle a plausible possibility that the numerically-based meaning of the rho in the tau-rho device stated by Ephraem might go back much earlier, and might even have been the originating impulse for the Christian appropriation of the device.

But there are some reasons to hesitate. Precisely given the evidence of a readiness among Christian in the first few centuries to employ isosephy, it is curious that we have no hint that the tau-rho was interpreted in this way earlier than Ephraem. Moreover, there is to my knowledge no evidence that the number 100 featured in

46 Dölger, Sol Salutis, 74.

47 As is well known, there is some textual variation in manuscripts of Revelation, the best supported number being 666, but some witnesses reading 616 ( $\mathfrak{P}^{115}$ [= P.Oxy. LVI 4499] C and Irenaeus), and even 665 (the minuscule 2344).

48 Hurtado, "Origin," 665-69.

49 To cite another example, the number eight was appropriated by early Christians as a symbol for the resurrection and eschatological hopes. See esp. F.J. Dölger, "Die Achtzahl in der altchristlichen Symbolik," Antike und Christentum 4 (1934) 153-87; R. Staats, "Ogdoas als ein Symbol für die Auferstehung," VigChr 26 (1972) 29-52. 
second-century Christian isosephy or that the word $\beta$ on $\theta$ i $\alpha$ was particularly prominent in Christian vocabulary of that period. Indeed, Ephraem's strong interest in finding mystical symbols of his faith everywhere in the world and nature suggests that the numerical interpretation of his tau-rho which he proposes may be his own contribution. Most significantly, Ephraem was commenting on the Christian use of a "free-standing" tau-rho device, that is, the tau-rho used on its own as a Christian symbol, such as we see in the Armant inscription cited previously. ${ }^{50}$

But I contend that this much later free-standing use of the tau-rho is significantly different from what we have in the earliest evidence of Christian use of the device, in which it appears within texts and as part of the marking off of words that refer to Jesus' cross/crucifixion. That is, in our earliest evidence of its Christian use, the tau-rho consistently appears in a crucial context as part of a text that has to do with Jesus' death. Used as a free-standing symbol, however, a device such as the tau-rho invites, perhaps requires, some imaginative interpretation such as Ephraem offered. But used in the way that we have the device employed in $\mathfrak{P}^{66}, \mathfrak{P}^{75}$ and $\mathfrak{P}^{45}$, the tau-rho takes its Christian meaning and function from the words of which it is a crucial part, and the sentences in which it is deployed.

This leads us to another intriguing possibility. The tau-rho device may have been appropriated by Christians originally, not (or not simply) on the basis of numerical symbolism, but because it could function as a visual reference to the crucified Fesus. This is not an original suggestion, but was proposed previously, notably by K. Aland and then supported strongly by E. Dinkler. ${ }^{51}$ In this proposal, the tau-rho device was appropriated initially because it could serve as a stylized reference to (and representation of) Jesus on the cross. The tau is confirmed as an early symbol of the cross, and the loop of the superimposed rho in the tau-rho suggested the head of a crucified figure. This very simple pictogram reference to the crucifixion of Jesus fits with the simplicity and lack of decorative detail that

\footnotetext{
${ }^{50}$ Finegan, Archaeology, 387-88. Granted, the free-standing form of the tau-rho that Ephraem comments on includes the use of the alpha and omega symbols as well, but this is only a more elaborate version of the sort of free-standing use of the tau-rho we have reflected in the Armant inscription.

${ }^{51}$ Aland, "Bemerkungen"; Dinkler, Signum Crucis, 177-78.
} 
characterizes earliest Christian art. As Robin Jensen notes in her recent excellent introduction to early Christian art, the simple nature of the visual expressions of faith in the earliest material "suggests that communication was valued above artistic quality or refinement and that the emphasis was on the meaning behind the images more than on their presentation." ${ }^{52}$ Commendably, Jensen notes the instances of the tau-rho device in the early papyri to which I draw attention in this essay, characterizing the combined letters as forming "a kind of pictogram, the image of a man's head upon a cross," and observing that the device "seems to be an actual reference to the cross of crucifixion ..."

The wider importance of this view of the tau-rho is considerable. As Dinkler put it in his enthusiastic endorsement of Aland's study,

Mit Recht macht Aland darauf aufmerksam, dass somit das Staurogramm älter ist als das Christogramm [chi-rho] ... älter als jedes 'christliche' Bild, älter als die christianisierte oder auch schöpferisch-christliche Ikonographie, das Zeichen der Christen für das Heilsereignis, für das Kreuz Christi ist. ${ }^{54}$

That is, if this proposal is correct, the tau-rho represents a visual reference to Jesus' crucifixion about 150 to 200 years earlier than the late fourth or fifth-century depictions that are usually taken by art historians as the earliest. ${ }^{55}$

\section{Significance FOR SGHOLARSHIP}

If in earliest Christian use the tau-rho is rightly referred to as a "staurogram", it is a noteworthy phenomenon to be reckoned with in charting the history of earliest Christian iconography. ${ }^{56}$ As I noted

${ }^{52}$ R.M. Jensen, Understanding Early Christian Art (London-New York 2000) 24.

${ }^{53}$ Jensen, Understanding, 138.

54 Dinkler, Signum Crucis, 178

${ }^{55}$ Two Christian intaglio gems usually dated to the fourth century, and a fifthcentury seal held in the Metropolitan Museum of Art in New York City are the frequently-cited items. For a discussion of these items and other relevant evidence, see now Jensen, Understanding, 131-41.

${ }^{56}$ A tau-rho written in red ink appears at the beginning of a single papyrus page containing Psalm 1:1 (Rahlfs 2116; van Haelst 84) dated initially (by A. Traversa to the second century. Writing before the publication of the early manuscript data that I underscore here, and under the influence of Sulzberger's thesis, C.R. Morey, Early Christian Art (Princeton 1953), 128, rejected this dating because he was confident 
in a previous publication, however, it is unfortunate that a good many historians of early Christian art are not aware of the staurogram (largely because early Christian manuscripts are not usually thought of as offering data for the study of art), and so do not take account of its import. ${ }^{57}$ But the staurogram is both important and rather unusual. In its earliest extant occurrences, it is a scribal device but entirely with a visual function, and so an iconographic phenomenon, a visual/material expression of early Christian faith/piety. Whether the tau-rho was adopted originally as a pictogram of the crucified Jesus (as I tend to think), or was interpreted more along the lines of Ephraem's numerical symbolism, either way it was a visual reference to the cross of Jesus.

Moreover, this has ramifications far beyond papyrology or the history of early Christian art. On what has been the dominant assumption that visual references to Jesus' crucifixion do not pre-date the fourth century $\mathrm{CE}$, some scholars have drawn far-reaching conclusions about the nature of Christian faith/piety in the pre-Constantinian period.$^{58}$ For instance, in a study of earliest archaeological evidence of Christianity with many other positive features, Graydon Snyder emphatically denied that there was any evidence of a visual reference to Jesus' crucifixion prior to the fourth century. ${ }^{59}$ On this basis, he then made the further dubious claim that there was "no place in the third century [or earlier] for a crucified Christ, or a symbol

that the Christian use of the tau-rho did not pre-date Constantine. Morey was right to suspect the second-century date of the manuscript, but his reason was wrong! Cf., e.g., Roberts, "P. Yale 1," 27-28.

57 Hurtado, "Earliest Evidence," 281-82. I cite there as an example of otherwise valuable histories of early Christian art that omit any reference to the staurogram, R. Milburn, Early Christian Art and Architecture (Berkeley 1988), but this omission is in fact typical of the genre.

${ }^{58}$ In an essay written before he became aware of the manuscript evidence of the Christian use of the staurogram, E. Dinkler, "Comments on the History of the Symbol of the Cross," Fournal for Theology and Church 1 (1965) 124-46 (German original 1951), once referred to the "absolute dogma that the symbol of the cross makes its first appearance in the age of Constantine" (ibid., 132), and claimed an absence of archaeological evidence of cross-marks made by Christians from the first two centuries (ibid., 134), reflecting, of course, the influential judgment by Sulzberger (cited above).

59 Snyder, Ante Pacem, 26-29 (I have not yet had access to the revised edition of this work which appeared in 2003, but from reviews it appears that it does not rectify the inadequately informed view of the matter expressed in first edition). 
of divine death." ${ }^{\prime 60}$ But Snyder showed no awareness of the staurogram, and so his estimate of cross-symbolism in the pre-Constantinian period is simply wrong. ${ }^{61}$ We can also say, therefore, that his sweeping characterization of pre-Constantinian Christian piety/faith is equally questionable. In the earliest instances of Christian usage, the staurogram (again, whether taken as a pictogram or a numerical symbol) obviously makes reference to the crucifixion/cross of Jesus, and so (along with the abundant textual evidence) reflects an importance given to Jesus' crucifixion in Christian faith/piety, from at least as early as the late second century.

${ }^{60}$ Snyder, Ante Pacem, 29.

${ }^{61}$ I intend no particular condemnation of Snyder, for a failure to take account of the staurogram (and of the phenomena of early Christian manuscripts generally) is, sadly, rather widely demonstrated in contemporary studies of Christian origins. In a book currently in preparation, I aim to help students and scholars recognize the importance of the data offered: L.W. Hurtado, The Earliest Christian Artifacts: Manuscripts and Christian Origins (Grand Rapids, forthcoming 2006). 